\title{
Frequency of olfactory dysfunction in pregnant women with SARS-CoV-2 infection
}

\author{
Sebastián Carranza-Lira, ${ }^{1 *}$ Maritza García-Espinosa² and Oscar Moreno-Álvarez ${ }^{3}$ \\ ${ }^{1}$ Health Research Division; ${ }^{2}$ Clinical Department for Complications of the Second Half of Pregnancy; ${ }^{3}$ General Director's Office, Hospital de Gineco- \\ Obstetricia 4 "Luis Castelazo Ayala", Instituto Mexicano del Seguro Social. Mexico City, Mexico
}

\begin{abstract}
Introduction: In patients with COVID-19, olfactory dysfunction and anosmia have been reported, which in pregnant women occur in up to $24.2 \%$. Objective: To know the frequency at which pregnant women with SARS-CoV-2 infection have olfactory dysfunction. Methods: Age, gestational age, temperature, presence of nasal constipation or rhinorrhea, myalgia, headache, cough or chest pain were asked. Whether patients perceived and identified the scent of grape juice, coffee powder and menthol was evaluated. Central tendency and dispersion measures, frequencies and percentages were used. Sensitivity, specificity, positive and negative predictive value were calculated. Mann-Whitney's U-test and contrast of proportions were used for comparisons between groups. Results: There was a higher proportion of women with cough, headache, dyspnea, myalgia, odynophagia, rhinorrhea, chest pain, and anosmia in SARS-CoV-2-positive women. In patients without COVID-19, 88.9 \% detected each one of the scents; only $31.8 \%$ of the positive group detected grapes scent, $47.7 \%$ coffee and $59.1 \%$ menthol, which had the highest percentages of sensitivity (40\%), specificity (21\%), positive predictive value (59 \%) and negative predictive value (11\%). Conclusion: Olfactory dysfunction occurs in a significant percentage of pregnant women with COVID-19.
\end{abstract}

KEY WORDS: SARS-CoV-2. COVID-19. Olfactory dysfunction. Anosmia.

\section{Frecuencia de disfunción olfatoria en mujeres embarazadas con infección por SARS-CoV-2}

\section{Resumen}

Introducción: En pacientes con COVID-19 se ha reportado disfunción olfatoria y anosmia; en la mujer embarazada se presenta hasta en $\mathbf{2 4 . 2} \%$. Objetivo: Conocer la frecuencia con la que las mujeres embarazadas e infección por SARS-CoV-2 tienen disfunción olfatoria. Métodos: Se preguntó edad, edad gestacional, temperatura, presencia de constipación nasal o rinorrea, mialgias, cefalea, tos o dolor torácico, además de evaluar si las mujeres percibían e identificaban el aroma de jugo de uva, café en polvo y mentol. Se utilizaron medidas de tendencia central y dispersión, frecuencias y porcentajes. Se calculó sensibilidad, especificidad, valor predictivo positivo y negativo. La U de Mann-Whitney y el contraste de proporciones sirvieron para las comparaciones entre los grupos. Resultados: Hubo mayor proporción de mujeres con tos, cefalea, disnea, mialgias, odinofagia, rinorrea, dolor torácico y anosmia en mujeres positivas a SARS-CoV-2. De las pacientes sin COVID-19, 88.9 \% detectó cada uno de los aromas; solo $31.8 \%$ del grupo positivo detectó el aroma a uva, $47.7 \%$ el de café y $59.1 \%$ el de mentol, el cual tuvo los porcentajes más altos en sensibilidad (40\%), especificidad (21\%), valores predictivos positivo (59\%) y negativo (11\%). Conclusión: la disfunción olfatoria se presenta en un porcentaje importante de las mujeres embarazadas con COVID-19.

PALABRAS CLAVE: SARS-CoV-2. COVID-19. Disfunción olfatoria. Anosmia.

Correspondence:

*Sebastián Carranza-Lira

E-mail: drsebastiancarranza@gmail.com
Gac Med Mex. 2021;157:245-250

Contents available at PubMed

www.gacetamedicademexico.com

0016-3813/@ 2020 Academia Nacional de Medicina de México, A.C.. Published by Permanyer. This is an open access article under the CC BY-NC-ND license (http://creativecommons.org/licenses/by-nc-nd/4.0/). 


\section{Introduction}

SARS-CoV-2 virus is the cause of COVID-19 disease, which is transmissible from person to person and is associated with different symptoms, among which pharyngodynia and nasal congestion are the most common in the upper airways, reported in $12.4 \%$ and in between 3.7 and $88 \%$, respectively. ${ }^{1}$ The most common symptoms are fever $(85.6 \%)$, cough $(68.7 \%)$, fatigue $(39.4 \%)$ and dyspnea $(21.4 \%) ;^{2}$ however, olfactory dysfunction has also been found, with a frequency ranging from 34 to $68 \%$. $^{3}$

In a study where 60 cases were analyzed, $98 \%$ had olfactory dysfunction, and $58 \%$, anosmia, ${ }^{3}$ while in another analysis, smell and taste alterations were reported to occur in 85.6 and $88 \% .^{1}$ In one study that compared positive and negative COVID-19 patients regarding smell and taste loss, these symptoms were found to be more common in the former group (68\% vs. $16 \%$ and $71 \%$ vs. $17 \%$, respectively). ${ }^{4}$ In a study of hospitalized patients, the frequency of alterations was found to be higher in those with severe disease, although the differences were not statistically significant (taste, 1.5 and $2.5 \%$; smell, 2.0 and $2.5 \%$ in patients with severe and non-severe disease, respectively). ${ }^{5}$

Hyposmia or anosmia was recorded in $79.7 \%$ of the patients with nasal obstruction or rhinorrhea, and in $11.8 \%$, it constituted an early symptom prior to the onset of others. ${ }^{1,4,6}$

In pregnant women, anosmia was reported to occur in $24.2 \%$ of those with COVID-19. In pregnant women without COVID-19, the frequency of hyposmia has been reported to be $7.1 \%$, while in non-pregnant women it is $2.9 \%{ }^{8}$

Prolonged anosmia was observed in patients with SARS-CoV-2 infection; $40 \%$ to $60 \%$ of the cases recovered spontaneously, although only $15 \%$ with anosmia and $25 \%$ with hyposmia recovered normal olfaction. ${ }^{9}$

In the case of SARS-CoV-2 infection, the mechanism by means of which the olfactory epithelium is affected and, therefore, olfaction is impaired, is not known; however it has been suggested that there is damage to the olfactory bulb and an inflammatory process that temporarily prevents odors detection. ${ }^{9}$ It has also been suggested that angiotensin-converting enzyme 2 (ACE2) receptors and transmembrane serine protease 2 are involved in the olfactory epithelium, which are necessary for transferring odors to neurons. ${ }^{10,11}$

There are several tests for olfactory dysfunction evaluation, and one of them is the Affordable Rapid Olfaction Measurement Array (AROMA), which evaluates 14 scents. Other shorter versions evaluate 12 items and another, four; the latter with a sensitivity of $91.2 \% .^{12}$

The purpose of the present study was to know the frequency of olfactory dysfunction in pregnant women with SARS-CoV-2 infection.

\section{Methods}

This was an observational, cross-sectional, prospective, comparative, open-label, controlled study, where two groups of women were evaluated:

- Group I, pregnant women with SARS-CoV-2 infection corroborated by PCR, evaluated in the triage area or hospitalized at the COVID area.

- Group II, pregnant women in whom COVID-19 was suspected and who were hospitalized; once admitted, RT-PCR test was performed, which was negative for SARS-CoV-2.

Women with a SARS-CoV-2 positive test on their evaluation at hospital admission were consecutively included. All women were investigated for a history of diabetes, chronic hypertension, asthma, smoking, lung disease, heart disease, kidney disease, and immunodeficiency secondary to HIV.

Women with nasal alterations, history of nasal surgery, use of medications that could modify olfaction (chronic use of nasal drops or inhaled substances) or with severe COVID-19, or who could not read the informed consent or in whom the test could not be practiced were not included. In addition, puerperal women were not included.

After the women signed the informed consent document, age (years), weight $(\mathrm{kg})$, height $(\mathrm{m})$, body mass index (BMl, $\mathrm{kg} /$ height in $\mathrm{m}^{2}$ ) were recorded; a BMI $\leq 25$ was considered normal, $>25$ to 30 indicated overweight, and $>30$, obesity. The number of pregnancies, deliveries, abortions, cesarean sections and gestational age of the pregnancy at the time of the investigation, as well as presence of cough, headache, dyspnea, myalgia, arthralgia, odynophagia, nasal constipation or rhinorrhea, conjunctivitis, chest pain and anosmia were investigated. Temperature $\left({ }^{\circ} \mathrm{C}\right)$, heart rate (normal $\leq 90$ beats/minute $[\mathrm{bpm}]$ ), respiratory rate (normal $\leq 20$ breaths/minute [brpm]) and oxygen saturation (normal $\geq 90 \mathrm{mmHg}$ ) were documented. 
Subsequently, the women were handed three Eppendorf tubes, each one containing grape juice, coffee powder, and menthol-camphor-eucalyptus (Vick VapoRub $^{\circledR}$, Vick México). They were asked if they perceived each scent and if they identified them. OIfactory dysfunction was considered to be partial or total inability to correctly perceive the scents, which was evaluated based on the number of identified scents: none, one out of three, two out of three, three out of three.

For sample size calculation, an alpha-type error of 0.01 and beta error of 0.05 were considered, with a frequency of olfactory dysfunction of $60 \%$ in group I and $5 \%$ in group II (without infection). Based on a $3: 1$ ratio between groups, 43 and 15 patients were determined for groups I and II (MedCalc Statistical Software, version 18.5, MedCalc Software, Ostend, Belgium; http://www.medcalc.org)

Central tendency and dispersion measures, as well as frequencies and percentages were used. Mann-Whitney's U-test was used for comparisons of continuous variables between groups, and for nominal variables, contrast of proportions (chi-square).

Sensitivity, specificity, positive predictive value (PPV) and negative predictive value (NPV) were calculated. The project was authorized by the Research Ethics Committee and the Local Health Research Committee, with registration number R-2020-3606-022; the patients granted their consent to participate.

\section{Results}

Sixty two patients were studied, 44 in group I and 18 in group II. Median age was 29 years (16-41) in group I, and 30.5 years (22-43) in group II. When the number of pregnancies, deliveries, abortions and cesarean sections, as well as weeks of gestation were compared, there were no differences between groups (Table 1).

There was no difference between groups I and II in terms of weight: $75.5 \mathrm{~kg}(56-94) \mathrm{vs} .77 \mathrm{~kg}(54-113)$, $\mathrm{p}<0.207$; height: $1.59 \mathrm{~m}(1.47-1.74)$ vs. $1.57 \mathrm{~m}(1.40-$ 1.65), $\mathrm{p}<0.207$; or BMl: 29.7 (21.9-36.7) vs. 30.1 (21.144.1), $p<0.987$.

When both groups were compared, the proportion of women with cough, headache, dyspnea, myalgia, odynophagia, rhinorrhea, chest pain and anosmia was found to be significantly higher in group I. The symptoms with the highest sensitivity were cough,
Table 1. Age and obstetric data in pregnant women positive and negative for SARS-CoV-2 infection

\begin{tabular}{|l|c|c|c|}
\hline Variable & $\begin{array}{c}\text { Positive } \\
(\mathrm{n}=44)\end{array}$ & $\begin{array}{c}\text { Negative } \\
(\mathrm{n}=18)\end{array}$ & $p$ \\
\hline Age, years & $29(16-41)$ & $30.5(22-43)$ & 0.798 \\
\hline Weeks of gestation & $34(8-40)$ & $34.5(8-38)$ & 0.809 \\
\hline Pregnancies & $2(1-6)$ & $2(1-6)$ & 0.832 \\
\hline Deliveries $^{*}$ & $0(0-2)$ & $0(0-3)$ & 0.183 \\
\hline Abortions $^{*}$ & $0(0-3)$ & $0(0-4)$ & 0.912 \\
\hline Cesarean sections $^{*}$ & $0(0-1)$ & $0(0-2)$ & 0.962 \\
\hline
\end{tabular}

*Data are presented as the mean (upper and lower limits).

conjunctivitis and chest pain, all with $100 \%$; those with the highest specificity were cough $(94 \%)$, headache $(61 \%)$ and anosmia $(61 \%)$. The symptoms with the highest PPV were cough (94\%), fever (64\%) and headache (48\%), and the symptoms with the highest NPV were cough, conjunctivitis and chest pain, all with $100 \%$ (Table 2).

Heart rate was significantly higher in group I when compared to group II: $100 \mathrm{bpm}$ (70-151) vs. $79 \mathrm{bpm}$ (60-197), $p<0.008$. As for respiratory rate, there was no significant difference between groups I and II: 20.5 brpm (14-38) vs. 22 brpm (14-23), p < 0.820. Oxygen saturation was significantly higher in group II in comparison with group I: $95.5 \%$ (78-98) vs. $94 \%(66-98)$, $p<0.042$.

The proportion of women with a heart rate $>90 \mathrm{bpm}$ was higher in group I in comparison with group II: $59.1 \%(n=26)$ vs. $16.7 \%(n=3), p<0.004$. There was no difference in the proportion of women with respiratory rate $>20 \mathrm{brpm}$ in groups I and II: $50.0 \%$ $(n=22)$ vs. $61.1 \%(n=11), p<0.576$. Similarly, there was no difference in the proportion of women with oxygen saturation < $90 \mathrm{mmHg}: 15.9 \%(n=8)$ vs. $5.6 \%(n=1), p<0.418$.

Heart rate had a sensitivity of $78 \%$ and specificity of $67 \%$, followed by oxygen saturation, with a sensitivity of $74 \%$ and specificity of $53 \%$, and respiratory rate, with a sensitivity of $45 \%$ and specificity of $44 \%$. As for PPV, the highest value was for heart rate (59\%), followed by respiratory rate $(50 \%)$ and oxygen saturation (16\%). NPV was higher for oxygen saturation $(94 \%)$, followed by heart rate $(83 \%)$ and respiratory rate $(39 \%)$.

In $45.5 \%$ of women in group I and $16.7 \%$ in group II, heart rate was found to have reached a value of 
Table 2. Symptoms in pregnant women positive and negative for SARS-CoV-2 infection

\begin{tabular}{|c|c|c|c|c|c|c|c|c|c|}
\hline \multirow[t]{2}{*}{ Symptom } & \multicolumn{2}{|c|}{$\begin{array}{l}\text { Positive } \\
(n=44)\end{array}$} & \multicolumn{2}{|c|}{$\begin{array}{c}\text { Negative } \\
(n=18)\end{array}$} & \multirow[t]{2}{*}{$p$} & \multirow[t]{2}{*}{ Sensitivity (\%) } & \multirow[t]{2}{*}{ Specificity (\%) } & \multirow[t]{2}{*}{ PPV (\%) } & \multirow[t]{2}{*}{ NPV (\%) } \\
\hline & $\mathrm{n}$ & $\%$ & $n$ & $\%$ & & & & & \\
\hline Fever & 28 & 63.6 & 8 & 44.4 & 0.134 & 59 & 60 & 64 & 56 \\
\hline Cough & 34 & 77.3 & 8 & 44.4 & 0.018 & 100 & 94 & 94 & 100 \\
\hline Headache & 21 & 47.7 & 3 & 16.7 & 0.025 & 74 & 61 & 48 & 83 \\
\hline Dyspnea & 13 & 29.5 & 1 & 5.6 & 0.049 & 84 & 57 & 30 & 94 \\
\hline Myalgia & 16 & 36.4 & 1 & 5.6 & 0.014 & 87 & 60 & 36 & 94 \\
\hline Arthralgia & 14 & 31.8 & 2 & 11.1 & 0.117 & 74 & 57 & 32 & 89 \\
\hline Odynophagia & 16 & 36.4 & 1 & 5.6 & 0.014 & 87 & 60 & 36 & 94 \\
\hline Rhinorrhea & 16 & 36.4 & 1 & 5.6 & 0.014 & 87 & 60 & 36 & 94 \\
\hline Conjunctivitis & 5 & 11.1 & 0 & 0 & 0.309 & 100 & 53 & 11 & 100 \\
\hline Chest pain & 14 & 31.8 & 0 & 0 & 0.006 & 100 & 59 & 32 & 100 \\
\hline Diarrhea & 5 & 11.1 & 2 & 11.1 & 1.0 & 51 & 50 & 11 & 89 \\
\hline Anosmia & 19 & 43.2 & 2 & 11.1 & 0.019 & 80 & 61 & 43 & 89 \\
\hline
\end{tabular}

Table 3. Positive detection of different scents by pregnant women positive and negative for SARS-CoV-2

\begin{tabular}{|c|c|c|c|c|c|c|c|c|c|}
\hline \multirow[t]{2}{*}{ Scent } & \multicolumn{2}{|c|}{$\begin{array}{l}\text { Positive } \\
(n=44)\end{array}$} & \multicolumn{2}{|c|}{$\begin{array}{c}\text { Negative } \\
(n=18)\end{array}$} & \multirow[t]{2}{*}{$p$} & \multirow[t]{2}{*}{$\begin{array}{c}\text { Sensitivity } \\
(\%)\end{array}$} & \multirow[t]{2}{*}{$\begin{array}{c}\text { Specificity } \\
(\%)\end{array}$} & \multirow[t]{2}{*}{$\begin{array}{l}\text { PPV } \\
(\%)\end{array}$} & \multirow[t]{2}{*}{$\begin{array}{l}\text { NPV } \\
(\%)\end{array}$} \\
\hline & $n$ & $\%$ & $n$ & $\%$ & & & & & \\
\hline Grape & 14 & 31.8 & 16 & 88.9 & $<0.000$ & 26 & 14 & 32 & 11 \\
\hline Coffee & 21 & 47.7 & 16 & 88.9 & $<0.004$ & 35 & 18 & 48 & 11 \\
\hline Menthol & 26 & 59.1 & 16 & 88.9 & $<0.035$ & 40 & 21 & 59 & 11 \\
\hline
\end{tabular}

$100 \mathrm{bpm}$, a cutoff point that had a sensitivity of $73 \%$, specificity of $60 \%$, PPV of $45.4 \%$ and NPV of $83.3 \%$.

Among the patients without COVID-19, $88.9 \%$ similarly detected each one of the scents; in group I, $31.8 \%(n=14)$ detected the scent of grape; $47.7 \%$ $(n=21)$, the scent of coffee; and $59.1 \%(n=26)$, the menthol scent.

The scent of grape had the lowest sensitivity, specificity, PPV and NPV; coffee had intermediate values, and menthol had the highest percentages in all four parameters: sensitivity of $40 \%$, specificity $21 \%$, PPV $59 \%$ and NPV $11 \%$ (Table 3).

Detection of all three scents was lower in the group of women with SARS-CoV-2 infection in comparison with women without infection: $31.8 \%(n=14)$ vs. $88.9 \%(n=16), p<0.001$. Regarding the number of detected scents, identification of three had a sensitivity of $26 \%$, specificity of $21 \%$, PPV of $44 \%$ and NPV of $11 \%$ (Table 4 ).

\section{Discussion}

SARS-CoV-2 infection is known to be associated with olfactory dysfunction of varying degrees in 34 to $98 \%$ of cases, with anosmia occurring in 58 to $71 \%,{ }^{3}$ which is a higher prevalence than that recorded in this study: $40.9 \%$ in group I women and $11.1 \%(n=2)$ in group II, in comparison with a reported prevalence of $7.1 \% .^{8}$

Regarding symptoms, the most common have been reported to be fever ( $85.6 \%)$, cough (68.7\%), fatigue $(39.4 \%)$ and dyspnea $(21.4 \%),{ }^{2}$ whereas in this study 
Table 4. Number of different scents correct detections by pregnant women positive and negative for SARS-CoV-2

\begin{tabular}{|c|c|c|c|c|c|c|c|c|}
\hline \multirow[t]{2}{*}{ Number of detections } & \multicolumn{2}{|c|}{$\begin{array}{l}\text { Positive } \\
(n=44)\end{array}$} & \multicolumn{2}{|c|}{$\begin{array}{l}\text { Negative } \\
(n=18)\end{array}$} & \multirow[t]{2}{*}{$\begin{array}{c}\text { Sensitivity } \\
(\%)\end{array}$} & \multirow[t]{2}{*}{$\begin{array}{c}\text { Specificity } \\
(\%)\end{array}$} & \multirow[t]{2}{*}{$\begin{array}{l}\text { PPV } \\
(\%)\end{array}$} & \multirow[t]{2}{*}{$\begin{array}{l}\text { NPV } \\
(\%)\end{array}$} \\
\hline & $n$ & $\%$ & $n$ & $\%$ & & & & \\
\hline None $^{*}$ & 18 & 40.9 & 2 & 11.1 & - & - & - & - \\
\hline 1 out of 3 & 5 & 11.4 & 0 & 0 & 100 & 21 & 22 & 100 \\
\hline 2 out of 3 & 7 & 15.9 & 0 & 0 & 100 & 21 & 28 & 100 \\
\hline 3 out of $3^{*}$ & 14 & 31.8 & 16 & 88.9 & 26 & 21 & 44 & 11 \\
\hline
\end{tabular}

the most common were cough $(63.6 \%)$, headache $(77.3 \%)$, dyspnea $(47.7 \%)$ and myalgia $(29.5 \%){ }^{13}$ In another study, baseline symptoms in the entire population were reported to be fever (54\%), cough (66\%) and dyspnea (25\%), which in the group with severe disease had a frequency of 93,86 and $57 \%$, respectively. ${ }^{14}$

The symptoms with the highest sensitivity were cough, conjunctivitis and chest pain, all with $100 \%$, while those with the highest specificity were cough (94\%), headache $(61 \%)$ and anosmia $(61 \%)$. Cough $(94 \%)$, fever (64\%) and headache (48\%) were the symptoms with the highest PPV; cough, conjunctivitis, and chest pain were the symptoms with the highest NPV, all with $100 \%$.

In another investigation, a respiratory rate $>20$ brpm was documented in $43 \%$ of cases, heart rate > $100 \mathrm{bpm}$ in $37 \%$, and oxygen saturation $>95 \mathrm{mmHg}$ in $18 \%{ }^{14}$ in the present study, a heart rate $>90 \mathrm{bpm}$ was observed in $59.1 \%$. When a heart rate of 100 bpm was considered as cutoff point, it was found in $45.5 \%$ of pregnant women with COVID-19, similar to previously reported observations,,$^{14}$ and in $16.7 \%$ of pregnant women without SARS-CoV-2 infection, with a sensitivity of $73 \%$, specificity of $60 \%$, PPV of 45.4 $\%$ and NPV of $83.3 \%$.

In this study, only three scents were used to assess olfaction, with this simplified test constituting a strength that allowed discriminating between groups. Of the three evaluated scents, menthol obtained the highest sensitivity, specificity, PPV and NPV $(40,21$, 59 and $11 \%$, respectively).

Based on the above, it is possible to conclude that olfactory dysfunction occurs in a significant percentage of pregnant women with COVID-19.

\section{Conflict of interests}

The authors declare that they have no conflicts of interest.

\section{Funding}

The authors did not receive any sponsoring to carry out this article.

\section{Ethical disclosures}

Protection of human and animal subjects. The authors declare that they did not perform any experiments on humans or animals for this research.

Confidentiality of data. The authors declare that they followed the protocols of their work center on the publication of patient data.

Right to privacy and informed consent. The authors declare that they obtained informed consent from the patients or subjects referred to in the article, and that the documentation is in the possession of the corresponding author.

\section{References}

1. Lechien JR, Chiesa-Estomba CM, de Siati DR, Horoi M, Le Bon SD, Rodríguez A, et al. Olfactory and gustatory dysfunctions as a clinical presentation of mild-to-moderate forms of the coronavirus disease (COVID-19): a multicenter European study. Eur Arch Otorhinolaryngol. 2020;277:2251-2261.

2. Lovato A, De Filippis C. Clinical presentation of COVID-19: a systematic review focusing on upper airway symptoms. Ear Nose Throat J Ear Nose Throat J. 2020:145561320920762.

3. Moein ST, Hashemian SMR, Mansourafshar B, Khorram-Tousi A, Tabarsi P, Doty RL. Smell dysfunction: a biomarker for COVID-19. Int Forum Allergy Rhinol. 2020;10:944-950.

4. Yan $\mathrm{CH}$, Faraji F, Prajapati DP, Boone CE, DeConde AS. Association of chemosensory dysfunction and COVID-19 in patients presenting with influenza-like symptoms. Int Forum Allergy Rhinol. 2020;10:806-813.

5. Mao L, Jin H, Wang M, Hu Y, Chen $S, H e$, et al. Neurologic manifestations of hospitalized patients with coronavirus disease 2019 in Wuhan, China. JAMA Neurol. 2020;77:1-9. 
6. Russell B, Moss C, Rigg A, Hopkins C, Papa S, van Hemelrijck M Anosmia and ageusia are emerging as symptoms in patients with $\mathrm{CO}$ VID-19: what does the current evidence say? Ecancermedicalscience. 2020;14:ed98.

7. Fox NS, Melka S. COVID-19 in pregnant women: case series from one large New York City obstetrical practice. Am J Perinatol. 2020;37:1002-1004.

8. Nwankwo U, Fasunla AJ, Oladokun A, Nwaorgu OG, William SR. Comparison between olfactory function of pregnant women and non-pregnant women in reproductive age group in Ibadan, Nigeria. Niger J Clin Pract. 2017;20:610-615.

9. Soler ZM, Patel ZM, Turner JH, Holbrook EH. A primer on viral-associated olfactory loss in the era of COVID-19. Int Forum Allergy Rhinol. 2020;10:814-820

10. Xydakis MS, Dehgani-Mobaraki P, Holbrook EH, Geisthoff UW, Bauer C Hautefort C, et al. Smell and taste dysfunction in patients with COVID-19. Lancet Infect Dis. 2020:20:1015-1016.
11. Butowt R, Bilinska K. SARS-CoV-2: olfaction, brain infection, and the urgent need for clinical samples allowing earlier virus detection. ACS Chem Neurosci. 2020;11:1200-1203.

12. Joseph T, Auger SD, Peress L, Rack D, Cuzick J, Giovannoni G, et al. Screening performance of abbreviated versions of the UPSIT smell test. J Neurol. 2019;266:1897-1906.

13. Andrikopoulou M, Madden M, Wen T, Aubey JJ, Aziz A, Baptiste CD, et al. Symptoms and critical illness among patients with coronavirus disease 2019 (COVID-19) infection. Obstet Gynecol. 2020; 136:291-299.

14. Savasi VM, Parisi F, Patanè L, Ferrazzi E, Frigerio L, Pellegrino A, et al Clinical findings and disease severity in hospitalized pregnant women with coronavirus disease 2019 (COVID-19). Obstet Gynecol. 2020; 136:252-258. 